\section{Competitiveness of the Selected Balkan Countries in the Period 2006-2015}

\author{
Vladimir Nedić, Vinko Lepojević, \\ Danijela Despotović, Dušan Cvetanović
}

JEL: O30, M30

\section{INTRODUCTORY REMARKS}

The concept of competitiveness refers to the ability of individuals, companies, communities, countries, and regions to compete and be better, more innovative, and more creative than other stakeholders on the local, national, regional, and global markets in creating value added. The concept of competitiveness is the result of a long history of scientific considerations, during which different narrower and broader views appeared, as well as numerous aspects specifying its content (Dragičević, 2012, p. 13). Due to the complexity of the concept, the diversity of factors, and the nature of the competitive processes, the category of competitiveness is often imprecisely defined (Snieška \& Bruneckienè, 2009).

Level, i.e. entity, taken into account when determining competitiveness, is undoubtedly the most important aspect of this concept (Annoni \& Kozovska, 2010., Kitson, Martin \& Tyler, 2004). The existing studies on competitiveness focus on different categories of analysis: the competitiveness of enterprises (micro level of competitiveness), sectoral competitiveness (meso level), regional competitiveness (space, town, locality, district, city, urban competitiveness) (Despotović, 2014; Nedić i Despotović, 2014), national competitiveness (macro level of competitiveness), macro-regional competitiveness, international competitiveness (global competitiveness, external competitiveness) (Figure 1):

In elementary terms, one should distinguish between microeconomic and macroeconomic aspects of the competitiveness complex. At the micro level, competitiveness is the ability of companies to compete, grow, and be profitable (Martin, 2004; Martin, 2003; Powell, 2001), or the ability of the company to produce and sell goods and services at a price that is lower than the competitors', or with other non-price factors that are more attractive than the competitors' offer (Hawkins, 2006). At this level, competitiveness is mainly reflected in the company's ability to consistently and profitably produce goods that meet market demands in terms of price, quality, etc. A company that is competitive in relation to its rivals will have a better chance to gain a larger market share. In contrast, non-competitive companies are characterized by a drop in market
Abstract: The paper considers the level of competitiveness of two groups of Balkan countries. The first group consists of neighboring countries of the Republic of Serbia that are not members of the EU (Albania, Bosnia and Herzegovina, Macedonia, Montenegro, Serbia), while the second group consists of five member states of the EU (Bulgaria, Croatia, Greece, Hungary and Romania). Research refers to a time period from 2006 to 2015. The level of competitiveness of countries is analyzed through the value of the Global Competitiveness Index of the World Economic Forum. Special focus is on Basic \& Efficiency factors based competitiveness, on the one hand, and Innovation \& Sophistication factors based competitiveness, on the other. The conclusion is that Serbia and the selected non-EU countries are lagging behind the group of EU countries, by all indicators. However, data for the observed period reveal trend of convergence of these groups' competitiveness.

Key words: country's competitiveness, GDP per capita, Basic requirements, Efficiency enhancers, Innovation and sophistication factors 


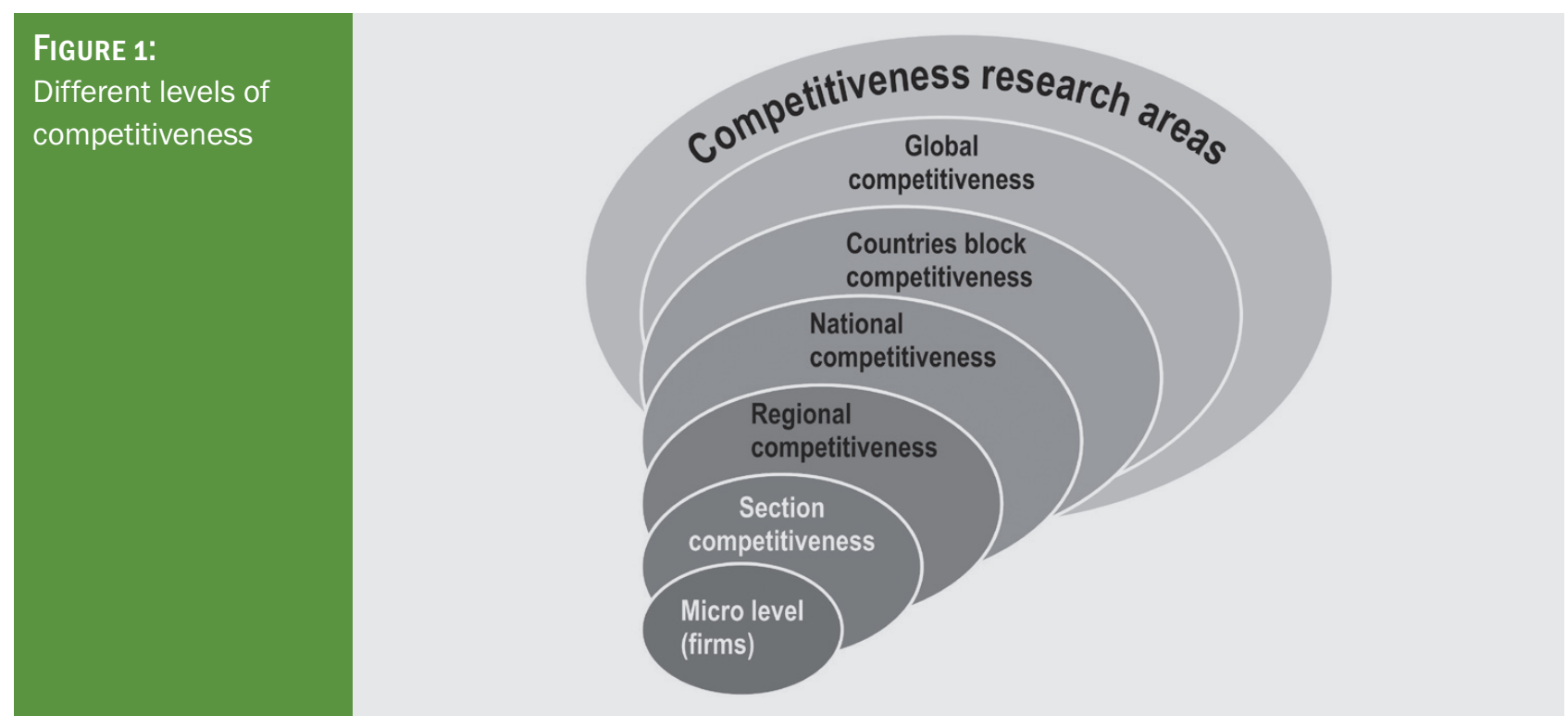

share and, in the end, if they cannot stop the decline in competitiveness, they get squeezed out of the market.

The concept of country's competitiveness was first determined by Michael Porter in his study in 1990 (Porter, 1990). In short, it is a country's ability to generate innovation in order to achieve or maintain an advantage compared to other countries in a number of key industries. Further studies show that, in the context of knowledge-based economies, countries should primarily develop specialization in order to achieve world-class living standards of their inhabitants (Huggins, 2005).

The key criterion for the distinction of country's competitiveness from company's competitiveness is a place these entities have in the creation of economic value in society. Economic values are created by companies only, and the country can establish an environment that supports or hinders their activities.

Between the macro and micro level, there is a strong and direct correlation (Schwab \& Porter, 2007; 2008). A number of authors believe that the definition of competitiveness refers to productivity, which measures the value of goods and services per unit of factors produced in a particular territory (Krugman, 1996; Ketels 2003; Ketels 2006). According to these authors, competitiveness aims to achieve greater productivity, which affects the growth of living standards.

At the micro level, methodology for measuring competitiveness is generally agreed. The most commonly used indicators of companies' competitiveness are those referring to market share in a given moment or the change in market share of a microeconomic entity over time. Among other important indicators, there are indicators of profitability, sales trends on the domestic and international market, and evaluation of the company ability to maintain and develop itself on a long-term basis in terms of growing international competition.

At the macro level, analysis of the country's competitiveness factors is an increasingly important dimension of development policy, which is largely devoted to finding ways to improve the quality of key economic performance. Although it is obvious that the concept of country's competitiveness is essentially linked to its economic performance, the fact is that it is increasingly seen in relation to the country's relative position to other countries, and far less in terms of its accumulated wealth. A common feature of all the measures that determine the level of country's competitiveness is multi-dimensionality. As there is a huge number of variables affecting it, it is necessary to develop an appropriate methodology for generalization, with the purpose of emphasizing the factors that have the greatest impact on competitiveness (Zubović \& Bradić-Martinović, 2013). It should be noted that a large number of economists are not interested in measuring the country's competitiveness (Schuller \& Lidbom, 2009). They argue that companies have to be competitive, not the countries, because when companies cannot compete, they disappear (Porter, 1990, 1998; Krugman, 1994; Schuller, 2008). On the other hand, the public and politicians are very interested in whether countries are competitive or not. To illustrate this, one of the goals of the Lisbon agenda of 2000 was that the EU becomes the most competitive world economy. 
Bearing this in mind, the authors define several research questions:

- What is the competitive advantage of the EU group of countries in relation to non-EU group of countries in the region, and how has it changed over the last decade?

- To what extent is competitiveness based on Basic \& Efficiency factors and to what extent on Innovation \& Sophistication factors, as seen by groups of countries?

- To what extent does Innovation \& Sophistication factors based competitiveness rely on the $11^{\text {th }}$ pillar: Business sophistication, and to what extent on the $12^{\text {th }}$ pillar: Innovation, judging by groups of countries?

- Furthermore, to what extent do the observed groups of countries use, individually speaking, innovation and sophistication factors to improve their competitive position?

Accordingly, the work attempts to analyze competitiveness of the Republic of Serbia and a group of selected Balkan countries in the region. At the same time, the comparison of two groups of European countries is carried out. The first group of countries includes countries in the immediate neighborhood of the Republic of Serbia, which do not belong to the
European Union (Albania, Bosnia and Herzegovina, Macedonia, Montenegro, and Serbia), while the second group includes five EU member states (Bulgaria, Croatia, Greece, Hungary, and Romania). The period to which the research relates extends from 2006 to 2015. In the course of the study, the level of competitiveness is analyzed through the value of the Global Competitiveness Index of the World Economic Forum in the period 2006-2015 (Global Competitiveness Report 2015-2016). Special focus is on Basic \& Efficiency factors based competitiveness, on the one hand, and Innovation \& Sophistication factors based competitiveness, on the other (Despotović, Cvetanović $\&$ Nedić, 2014). The structure of the work is adapted to the established goal.

\section{THE WEF'S METHODOLOGY FOR QUANTIFICATION OF COUNTRIES' COMPETITIVENESS}

Affirmation of the issue of countries' competitiveness at a global scale is associated dominantly with operation of the World Economic Forum (WEF) and its Global Competitiveness Index (GCI).

The Global Competitiveness Index is a composite indicator made up of 12 pillars of competitiveness

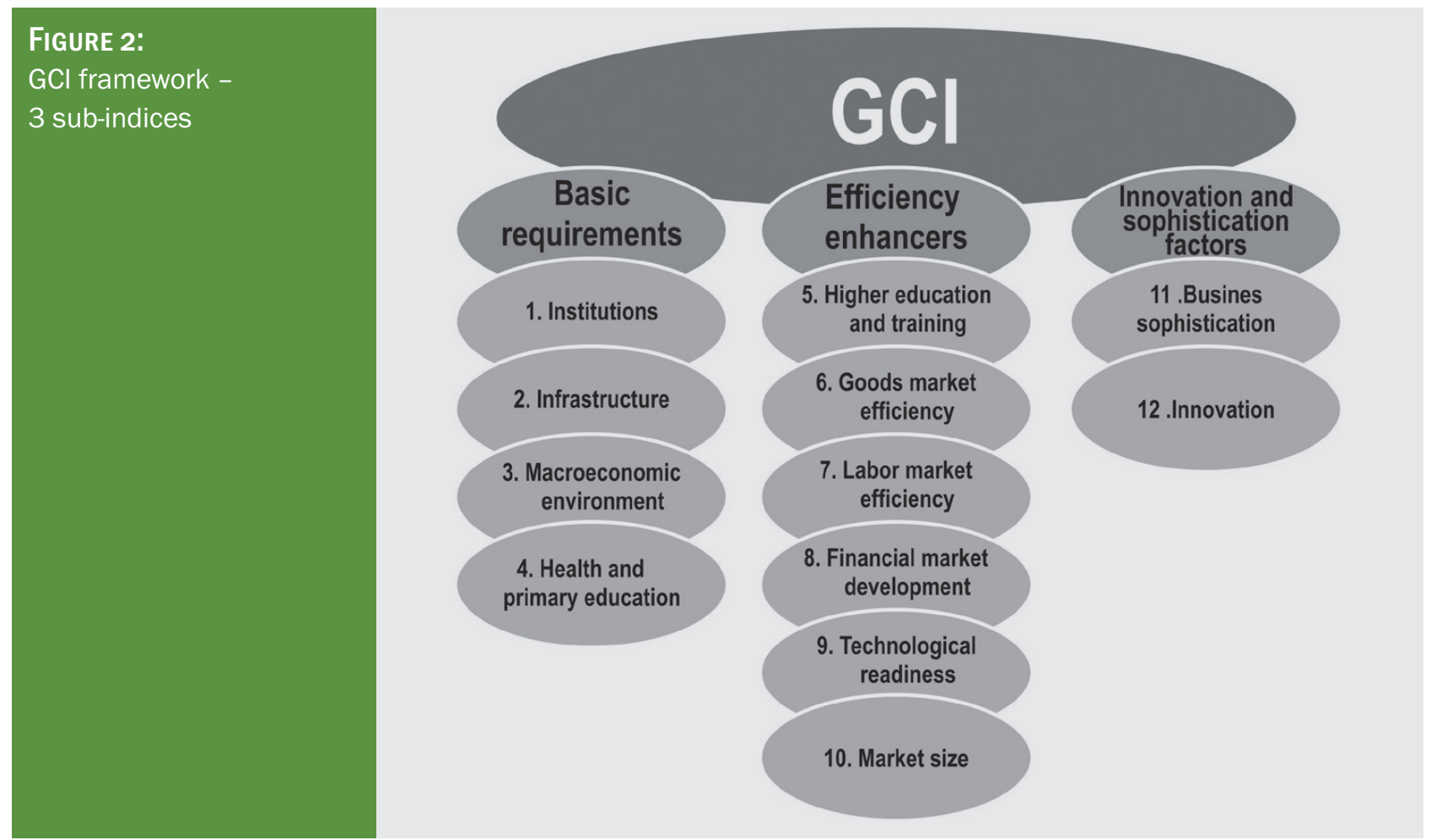

Source: Authors, with reference to Schwab, Sala-i-Martin, Semans \& Blanke et al., 2014, p.9. 
FigURE 3: Subindex weights for stages of development and transitional stages

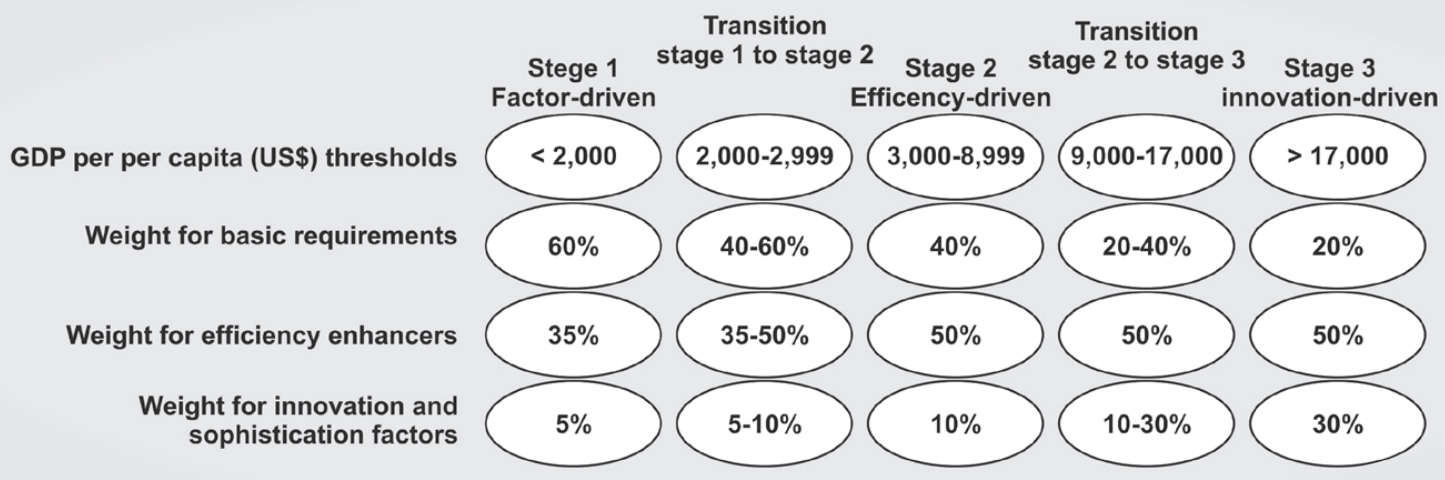

SouRcE: Authors, with reference to Schwab et al., 2014, p.10.

(Institutions, Infrastructure, Macroeconomic environment, Health and primary education, Higher education and training, Goods market efficiency, Labor market efficiency, Financial market development, Technological readiness, Market size, Business sophistication and Innovation) (Figure 2). The variables analyzed in each of these pillars have been used for more than three decades by the World Economic Forum.

The significance of certain groups of pillars of competitiveness depends on the country's stage of development (which is approximated by GDP per capita).

The first group of pillars (Basic requirements) is of the greatest importance for the least developed countries. In addition to Basic requirements, for countries at the middle development level (Serbia belongs to this group), Efficiency enhancers are important as well. Efficiency enhancers and Innovation and sophistication factors are of the greatest importance for the most developed countries (Figure 3).

Theoretically speaking, according to the World Economic Forum methodology, all countries go through three primary and two transitional stages of economic development (depending on the realized level of GDP per capita, denominated in US dollars). According to the research results presented in the Global Competitiveness Report 2015-2016 (Schwab et al., 2014, p. 38), the countries can be grouped into five groups:

- The first group consists of countries whose development is driven by basic requirements (the first stage of development). This group includes 35 countries.
- The second group consists of countries that are in transition between the first and second stage of development (16 countries);

- The third group consists of countries at the middle stage of development, whose key drivers of competitiveness are the pillars belonging to the group of "Efficiency enhancers" (31 countries)

- The fourth group consists of countries that are in transition from the second to the third stage of development (20 countries); and finally

- The fifth group includes the most developed countries (the third stage of development) in which the growth of productivity and competitiveness factors is caused by Innovation and sophistication factors (38 countries). (Figure 3 )

GCI is the basis for the international ranking of countries in terms of business climate. Although it brings benefits to international investors, its theoretical basis and aggregation procedure are subject of numerous disputes.

\section{COMPARATIVE ANALYSIS OF THE COMPETITIVENESS OF THE OBSERVED GROUPS OF COUNTRIES}

Research includes 10 Balkan countries, divided into two groups:

1. Non-EU neighboring countries of Serbia (Albania, Bosnia and Herzegovina, Macedonia, Montenegro, Serbia) and

2. EU neighboring countries of Serbia (Bulgaria, Croatia, Greece, Hungary, and Romania) (Figure 4). 
FigURE 4: Map of the observed groups of countries

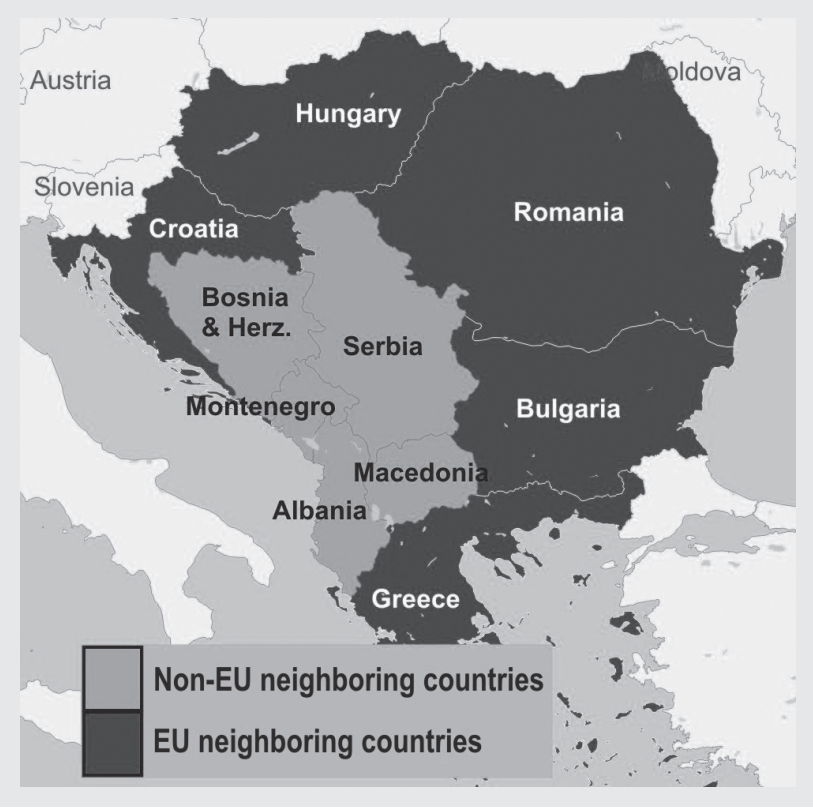

The observed countries are at different stages of economic development (Table 1).
Table 2 shows data on the GCI values for the first group consisting of non-EU neighboring countries of Serbia (Albania, Bosnia and Herzegovina, Macedonia, Montenegro, Serbia) for the period 2006-2015. The theoretical values of the GCI range from 1 to 7 .

The GCI trend in observed non-EU countries in 2006-2015 is illustrated by a diagram based on Table 2 data (Figure 5). It is evident that Montenegro shows the best results. It is followed by Macedonia, which is the only country with upward trend during the whole observed period. Serbia shows the most stagnant trend in the group. After initial rapid growth in competitiveness, Albania shows certain decline in the second third of the period, while Bosnia and Herzegovina shows significant and steady growth from 2010 to 2013, when significant drop in competitiveness occurred.

Table 3 shows data on the GCI values for the second observed group consisting of EU neighboring countries of Serbia (Bulgaria, Croatia, Greece, Hungary and Romania) for the period 2006-2015.

Figure 6 illustrates time series of the GCI values for this group of countries. Countries in the best positions

TABLE 1: Stages of development

\begin{tabular}{|c|c|c|c|c|c|}
\hline & $\begin{array}{c}\text { Stage 1: } \\
\text { Factor-driven: }\end{array}$ & $\begin{array}{l}\text { Transition Stage } \\
(1 \Rightarrow 2)\end{array}$ & $\begin{array}{c}\text { Stage 2: } \\
\text { Efficiency- } \\
\text { driven }\end{array}$ & $\begin{array}{c}\text { Transition Stage } \\
\qquad(2 \Rightarrow 3)\end{array}$ & $\begin{array}{c}\text { Stage 3: } \\
\text { Innovation- } \\
\text { driven }\end{array}$ \\
\hline Albania & & & $\checkmark$ & & \\
\hline $\mathrm{BIH} *$ & & & $\checkmark$ & & \\
\hline Bulgaria & & & $\checkmark$ & & \\
\hline Croatia & & & & $\checkmark$ & \\
\hline Greece & & & & & $\checkmark$ \\
\hline Hungary & & & & $\checkmark$ & \\
\hline Macedonia & & & $\checkmark$ & & \\
\hline Montenegro & & & $\checkmark$ & & \\
\hline Romania & & & & $\checkmark$ & \\
\hline Serbia & & & $\checkmark$ & & \\
\hline
\end{tabular}

SouRcE: Global Competitiveness Report 2015-2016

TABLE 2: The GCl of the non-EU countries group 2006-2015

\begin{tabular}{|l|c|c|c|c|c|c|c|c|c|c|} 
& $\mathbf{2 0 0 6 -}$ & $\mathbf{2 0 0 7 -}$ & $\mathbf{2 0 0 8 -}$ & $\mathbf{2 0 0 9 -}$ & $\mathbf{2 0 1 0 -}$ & $\mathbf{2 0 1 1 -}$ & $\mathbf{2 0 1 2 -}$ & $\mathbf{2 0 1 3 -}$ & $\mathbf{2 0 1 4 -}$ & $\mathbf{2 0 1 5 -}$ \\
& $\mathbf{2 0 0 7}$ & $\mathbf{2 0 0 8}$ & $\mathbf{2 0 0 9}$ & $\mathbf{2 0 1 0}$ & $\mathbf{2 0 1 1}$ & $\mathbf{2 0 1 2}$ & $\mathbf{2 0 1 3}$ & $\mathbf{2 0 1 4}$ & $\mathbf{2 0 1 5}$ & $\mathbf{2 0 1 6}$ \\
\hline Albania & 3.56 & 3.48 & 3.55 & 3.72 & 3.94 & 4.06 & 3.91 & 3.85 & 3.84 & 3.93 \\
\hline BIH* & 3.82 & 3.55 & 3.56 & 3.53 & 3.70 & 3.83 & 3.93 & 4.02 & $3.84 *$ & 3.71 \\
\hline Macedonia & 3.81 & 3.73 & 3.87 & 3.95 & 4.02 & 4.05 & 4.04 & 4.14 & 4.26 & 4.28 \\
\hline Montenegro & & 3.91 & 4.11 & 4.16 & 4.36 & 4.27 & 4.14 & 4.20 & 4.23 & 4.20 \\
\hline Serbia & & 3.78 & 3.90 & 3.77 & 3.84 & 3.88 & 3.87 & 3.77 & 3.90 & 3.89 \\
\hline
\end{tabular}

SOURCE: Global Competitiveness Report 2015-2016 


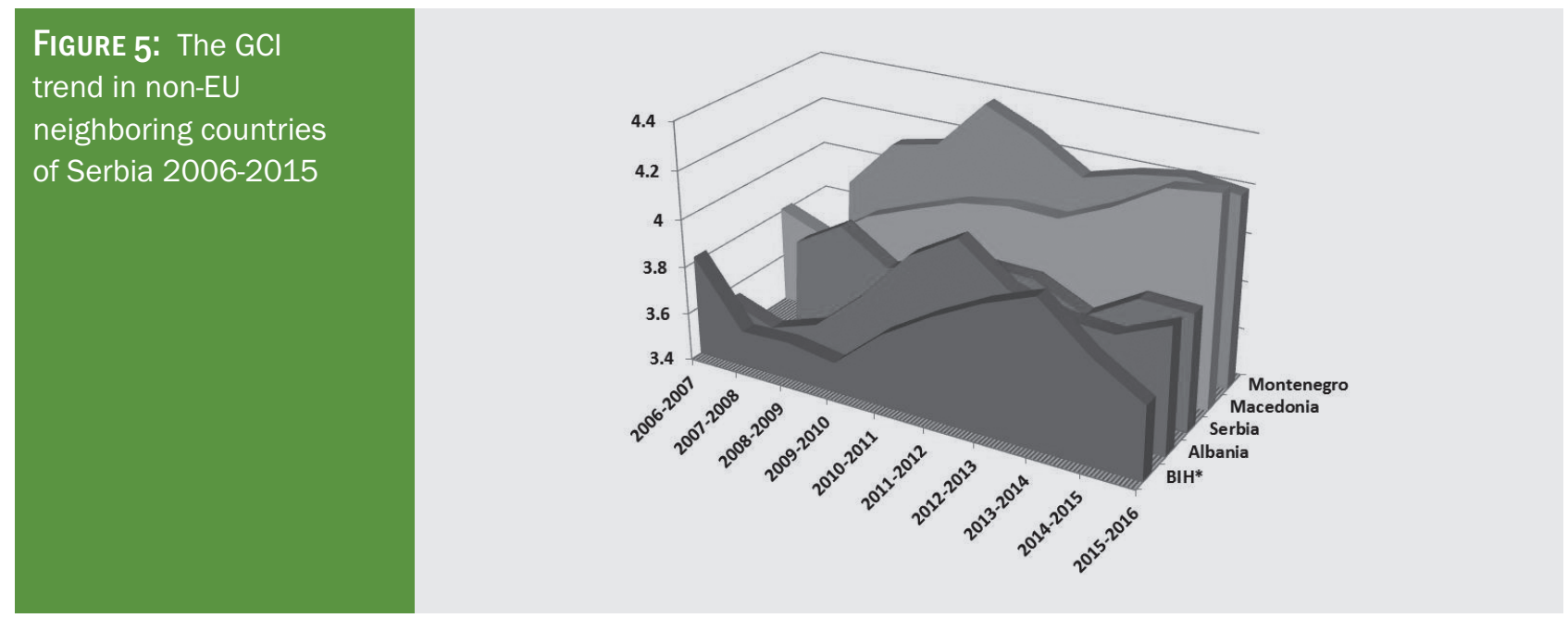

Source: Calculated according to Global Competitiveness Report 2015-2016. (n.d.)

TABLE 3: The GCl of the EU neighboring countries group 2006-2015

\begin{tabular}{|l|l|l|l|l|l|l|l|l|l|l|} 
& $\mathbf{2 0 0 6 -}$ & $\mathbf{2 0 0 7 -}$ & $\mathbf{2 0 0 8 -}$ & $\mathbf{2 0 0 9 -}$ & $\mathbf{2 0 1 0}$ & $\mathbf{2 0 1 1}$ & $\mathbf{2 0 1 2 -}$ & $\mathbf{2 0 1 3 -}$ & $\mathbf{2 0 1 4}$ & $\mathbf{2 0 1 5 -}$ \\
& $\mathbf{2 0 0 7}$ & $\mathbf{2 0 0 8}$ & $\mathbf{2 0 0 9}$ & $\mathbf{2 0 1 0}$ & $\mathbf{2 0 1 1}$ & $\mathbf{2 0 1 2}$ & $\mathbf{2 0 1 3}$ & $\mathbf{2 0 1 4}$ & $\mathbf{2 0 1 5}$ & $\mathbf{2 0 1 6}$ \\
\hline Bulgaria & 3.98 & 3.93 & 4.03 & 4.02 & 4.13 & 4.16 & 4.27 & 4.31 & 4.37 & 4.32 \\
Croatia & 4.16 & 4.20 & 4.22 & 4.03 & 4.04 & 4.08 & 4.04 & 4.13 & 4.13 & 4.07 \\
\hline Greece & 4.12 & 4.08 & 4.11 & 4.04 & 3.99 & 3.92 & 3.86 & 3.93 & 4.04 & 4.02 \\
\hline Hungary & 4.49 & 4.35 & 4.22 & 4.22 & 4.33 & 4.36 & 4.30 & 4.25 & 4.28 & 4.25 \\
\hline Romania & 3.98 & 3.97 & 4.10 & 4.11 & 4.16 & 4.08 & 4.07 & 4.13 & 4.30 & 4.32 \\
\hline
\end{tabular}

SourcE: Global Competitiveness Report 2015-2016. (n.d.)

at the beginning of the period (Hungary, Croatia, and Greece) have experienced the largest decline caused by the economic crisis, which is particularly detected in Greece. None of these countries has managed to regain the starting position. On the other hand, Bulgaria and Romania have had the worst starting positions but they have managed to maintain a positive trend and achieve significantly better results compared to the beginning of the period observed. It should be noted that Romania, unlike Bulgaria, has experienced a significant decline in 2011 and 2012 but has managed to turn it into a rapid growth, especially in 2014.
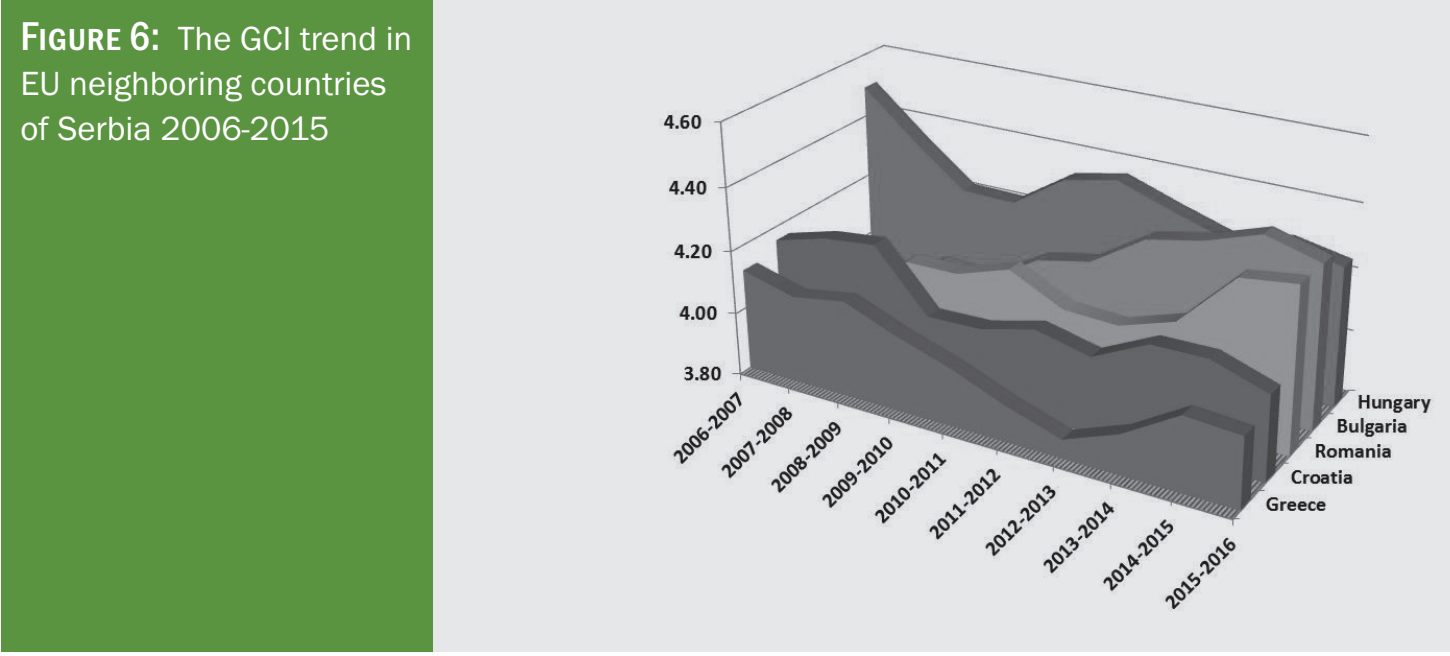

Source: Calculated according to Global Competitiveness Report 2015-2016. (n.d.) 


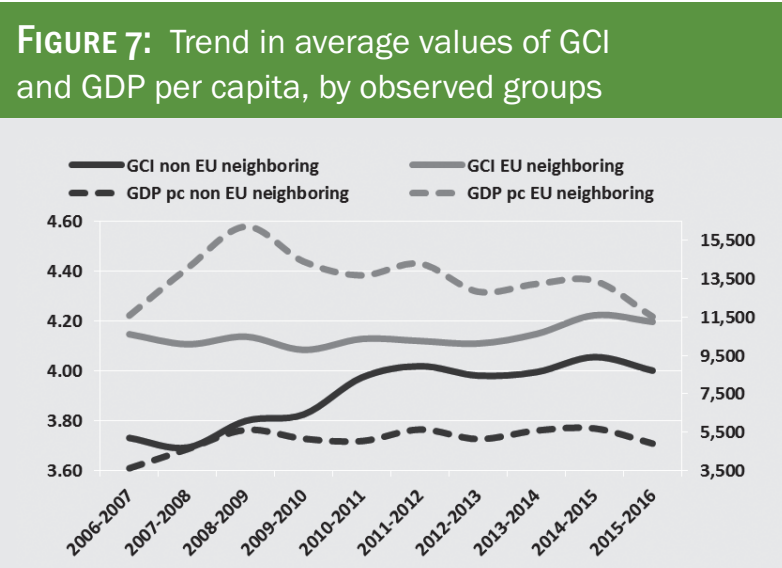

SourcE: Calculated according to Global Competitiveness Report 2015-2016. (n.d.)

After considering trends in competitiveness at the level of individual economies within the observed groups, next we provide the average values of GCI (as an indicator of competitiveness) and of GDP per capita (as an indicator of achieved level of economic development) by the observed groups of countries for the period 2006-2015. Average values for selected groups of countries are shown in the aggregate as an average of the results which observed groups of countries have achieved in terms of competitiveness and economic growth (Figure 7). Trend in economic growth is monitored by GDP per capita expressed in terms of constant prices (US\$).

Visually it can be concluded that there has been a strong trend of convergence of competitiveness for observed groups of countries until 2012, when it started to weaken. This trend is caused on the one hand by stagnation in the values of competitiveness in the EU neighboring countries group, and mostly by significant increase in competitiveness in the non-EU neighboring countries group, on the other hand. Also it can be noticed that the average value of GDP per capita of the EU neighboring countries group mainly shows a downward trend, while the average value of GDP per capita of the non-EU neighboring countries group remains approximately at the same level. It can be concluded that in the aggregate, non-EU neighboring countries of Serbia have managed to offset the economic crisis by improving competitiveness of their economies.

\section{BASIC \& EFFICIENCY FACTORS BASED COMPETITIVENESS AND INNOVATION \& SOPHISTICATION FACTORS \\ BASED COMPETITIVENESS OF THE OBSERVED GROUPS OF COUNTRIES}

In further research we compare time series of values of the Basic \& Efficiency factors based competitiveness and Innovation \& Sophistication factors based competitiveness, which are extracted from the GCI as components (Figure 8).

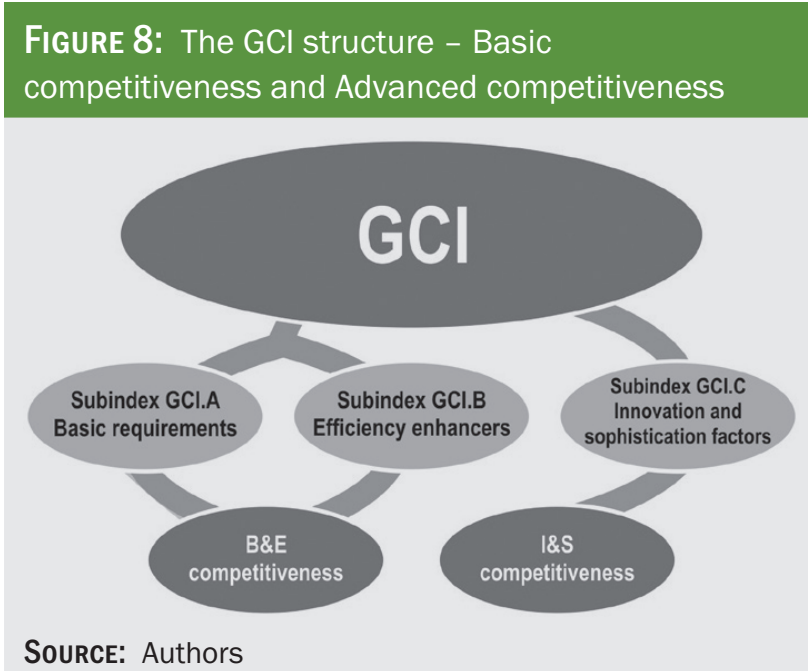

Since the GCI consists of three sub-indices, we assume that subindex A, Basic requirements, and subindex B, Efficiency enhancers, reflect the phenomenon of national competitiveness based on availability and efficient use of factors (Basic \& Efficiency factors based competitiveness, B\&E competitiveness), while subindex C, Innovation and sophistication factors, reflects national competitiveness generated by business innovation and sophistication (Innovation \& Sophistication factors based competitiveness, I\&S competitiveness).

We obtain the Basic \& Efficiency factors based competitiveness by adjusting and normalizing average of the sub-indices A and B. Adjustment coefficient is determined on the basis of weights of each of the GCI sub-indices, depending on the achieved stage of development of an economy (Figure 3). 


$$
\frac{\left(G C I \cdot A * W B_{S I}\right)+\left(G C I \cdot B * W E_{S I}\right)}{W B_{S I}+W E_{S I}} * 10
$$

where:

WB - weight of the GCI subindex A

WE - weight of the GCI subindex B

SI - stage of development of the observed economy $(\mathrm{I}=1-5)$

Based on the above defined and adjusted metrics, the accompanying diagrams (Figures 9 and 10) show the average values of the Basic \& Efficiency factors based competitiveness, the average values of Innovation \& Sophistication factors based competitiveness, as well as the average values of GDP per capita for the observed period.

FigURE 9: Average values for the non-

EU neighboring countries group

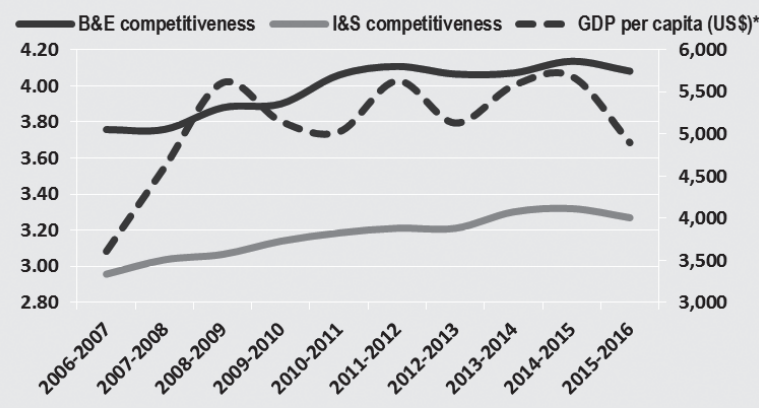

SourcE: Calculated according to Global Competitiveness Report 2015-2016. (n.d.)

There is a huge gap between the Basic \& Efficiency factors based competitiveness and Innovation \& Sophistication factors based competitiveness in the non-EU neighboring countries, as Figure 9 shows. But Figure 9 also shows that there is a trend of their slight but constant growth. Innovation \& Sophistication factors based competitiveness grows, demonstrating this group of countries' timid progress toward the innovation-driven economy.

On the other hand (Figure 10), although the EU neighboring countries group evidently has better results in terms of the basic competitiveness and in terms of Innovation \& Sophistication factors based competitiveness as well, because of their stagnant trend the gap between this group of countries and non-EU neighboring countries group is narrowing.

Based on the previous analyses, it can be concluded that:
FiguRE 10: Average values for the EU

neighboring countries group

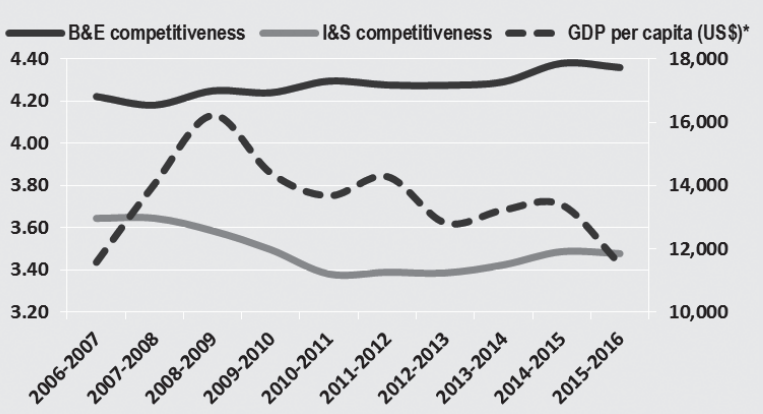

SourcE: Calculated according to Global Competitiveness Report 2015-2016. (n.d.)

- Both groups of countries observed have a dominant Basic \& Efficiency factors based competitiveness component in relation to Innovation \& Sophistication factors based competitiveness.

- Group of non-EU countries shows a slight and almost parallel growth of both competitiveness components observed, while the EU countries exhibit the trend of mild divergence of these components, which is primarily caused by a decline in the value of Innovation \& Sophistication factors based competitiveness.

- Trend of the average value of GDP per capita in the reporting period for non EU-group grows, while in the EU group it has a descending character.

To statistically check correlation between the growth rates of GDP per capita and the value of the two listed GCI index components, simple linear regression analysis is applied.

The following variables are included in the model:

X1 - B\&E competitiveness, as the first independent variable,

$\mathrm{X} 2$ - I\&S competitiveness, as the second independent variable,

$\mathrm{Y}-G D P p c$, as the dependent variable, $\mathrm{t}$ - time.

Individual dependence of variable Y (GDP pc) on independent variables (variables $\mathrm{X} 1, \mathrm{X} 2$ ) is defined:

$\mathrm{Y}(\mathrm{t}+\mathrm{n})=\mathrm{a} 0+\mathrm{a} 1^{\star} \mathrm{X} 1(\mathrm{t})$

$\mathrm{Y}(\mathrm{t}+\mathrm{n})=\mathrm{b} 0+\mathrm{b} 1^{\star} \mathrm{X} 2(\mathrm{t})$

where $t$ is year, and $n$ time lag between the dependent and independent variable. In our case, the time period for the observed groups is 10 years with a time lag of one year $(\mathrm{n}=1)$. 


\section{marketing}

TABLE 4: Descriptive statistics for non EU neighboring countries group

\begin{tabular}{|l|c|c|c|}
\hline Descriptive statistic & $\begin{array}{c}\text { X1 - B\&E } \\
\text { competitiveness }\end{array}$ & $\begin{array}{c}\text { X2 -Innovation and } \\
\text { sophistication factors }\end{array}$ & $\begin{array}{c}\text { Y-GDP pc (US\$), } \\
\text { current prices }\end{array}$ \\
\hline Time series & $2006-2015$ & $2006-2015$ & $2007-2016$ \\
\hline Mean & 3.99 & 3.18 & $5,247.44$ \\
\hline Standard Error & 0.03 & 0.04 & 156.94 \\
\hline Median & 3.98 & 3.16 & $4,838.15$ \\
\hline Standard Deviation & 0.22 & 0.25 & $1,075.90$ \\
\hline Range & 0.89 & 0.94 & $3,795.79$ \\
\hline Minimum & 3.55 & 2.72 & $3,594.10$ \\
\hline Maximum & 4.44 & 3.67 & $7,389.89$ \\
\hline Count & 47.00 & 47.00 & 47.00 \\
\hline Confidence Level(95.0\%) & 0.07 & 0.07 & 315.90 \\
\hline Coeff. of var. & 0.06 & 0.08 & 0.21 \\
\hline
\end{tabular}

Results of simple linear correlation with non EU neighboring countries group show statistically significant and almost identical positive impact of both independent variables on GDP pc. However, there is also a very strong multicollinearity between the two dependent variables, which prevents the setting up of a simple multiple correlation model. One possible solution is to include a higher level of decomposition

FigURE 11: Dependence of GDP pc on: a) B\&E competitiveness and b) I\&S

competitiveness for the non EU neighboring countries group

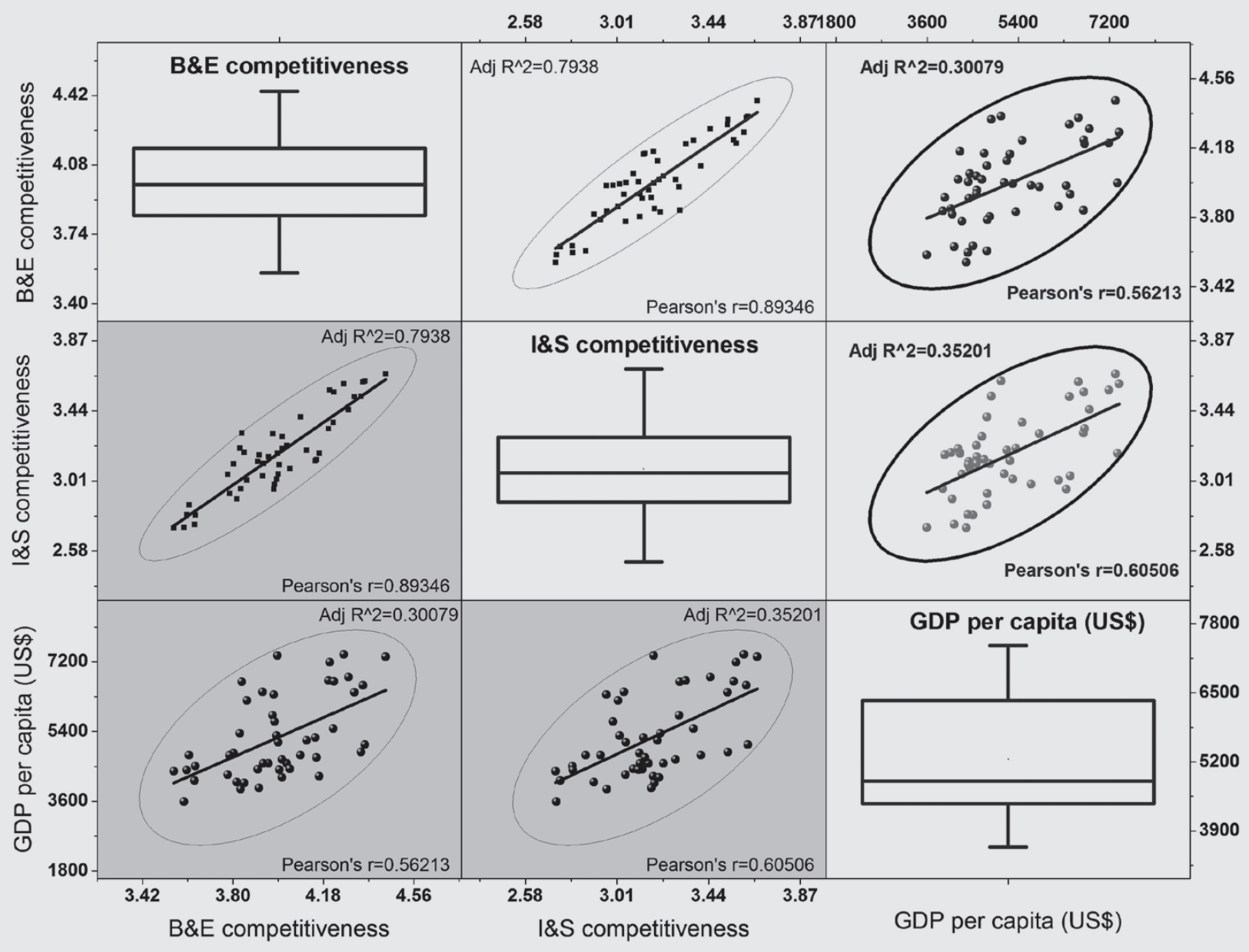


TABLE 5: Descriptive statistics for EU neighboring countries group

\begin{tabular}{|l|c|c|c|}
\hline Descriptive statistic & $\begin{array}{c}\text { X1 - B\&E } \\
\text { competitiveness }\end{array}$ & $\begin{array}{c}\text { X2 -Innovation and } \\
\text { sophistication factors }\end{array}$ & $\begin{array}{c}\text { Y-GDP pc (US\$), } \\
\text { current prices }\end{array}$ \\
\hline Time series & $2006-2015$ & $2006-2015$ & $2007-2016$ \\
\hline Mean & 4.28 & 3.49 & $13,527.11$ \\
\hline Standard Error & 0.02 & 0.03 & 920.62 \\
\hline Median & 4.26 & 3.47 & $12,871.00$ \\
\hline Standard Deviation & 0.14 & 0.20 & $6,509.79$ \\
\hline Range & 0.56 & 0.87 & $26,338.97$ \\
\hline Minimum & 4.00 & 3.20 & $5,859.05$ \\
\hline Maximum & 4.56 & 4.06 & $32,198.01$ \\
\hline Count & 50.00 & 50.00 & 50.00 \\
\hline Confidence Level(95.0\%) & 0.04 & 0.06 & $1,850.06$ \\
\hline Coeff. of var. & 0.03 & 0.06 & 0.47 \\
\hline
\end{tabular}

of the aggregate competitiveness and apply Principal Component Analysis, but it is beyond the scope of this study.
Unlike non EU, with EU neighboring countries group, analysis of single linear correlation of independent variables and the GDP per capita shows different nature of impact in the set model. While com-

FigURE 12: Dependence of GDP pc on: a) B\&E competitiveness and b) I\&S competitiveness for the EU neighboring countries group

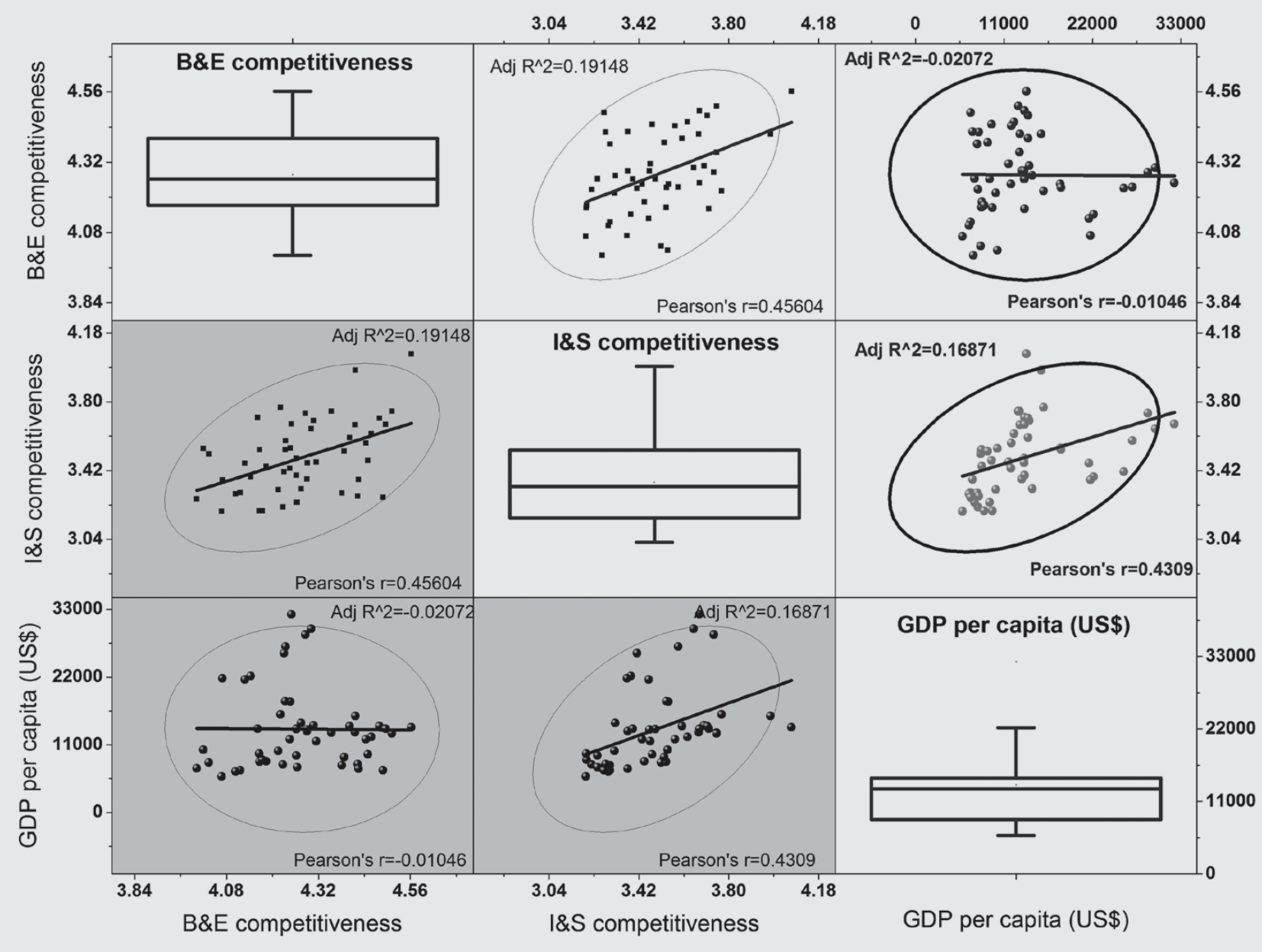


ponent X2 (I\&S competitiveness) has a statistically significant positive impact (although weaker than in non $\mathrm{EU}$ ), component X1(B\&E competitiveness) does not show any significant impact on the dependent variable $Y(G D P p c)$. that:

Based on the previous analyses, it can be concluded

- non-EU group of countries base their competitiveness on a balanced impact of both defined competitiveness components, which is expected, considering that most of them are in stage 2 (when they basically rely on basic and efficiency factors). To initiate their transition to stage 3 (when they basically rely on efficiency and innovation factors), the primary goal of these countries is to increase the use of innovation potential through: a) development of an efficient national innovation system, b) involvement in regional and global innovation systems and c) establishment of a network for efficient knowledge and innovation exchange between various participants in the innovation process, both at home and at EU level, as well as globally.

- On the other hand, with EU group of countries, there is obvious exhaustion of Basic and efficiency factors based competitiveness capacity, as expected, because these potentials are mainly activated during the process of their accession to the EU. These countries further increase their competitiveness based on innovation and sophistication factors.

- Finally, obvious compatibility of these two groups of countries in terms of their joint development of innovative potentials must be noted, through fine-tuning and harmonizing innovation policies at regional level and their quicker integration into innovation trends in EU developed countries and other world leaders.

\section{TWO PILLARS OF INNOVATION \& SOPHISTICATION FACTORS BASED COMPETITIVENESS IN THE OBSERVED GROUPS OF COUNTRIES}

For deeper consideration of Innovation \& Sophistication factors based competitiveness, the values of their component pillars (pillars 11 and 12) were further compared, according to the GCI framework (the structure of these pillars is given in Figure 13.
FIGURE 13: $\mathrm{GCl}$ innovativeness and

market sophistication sub-indices

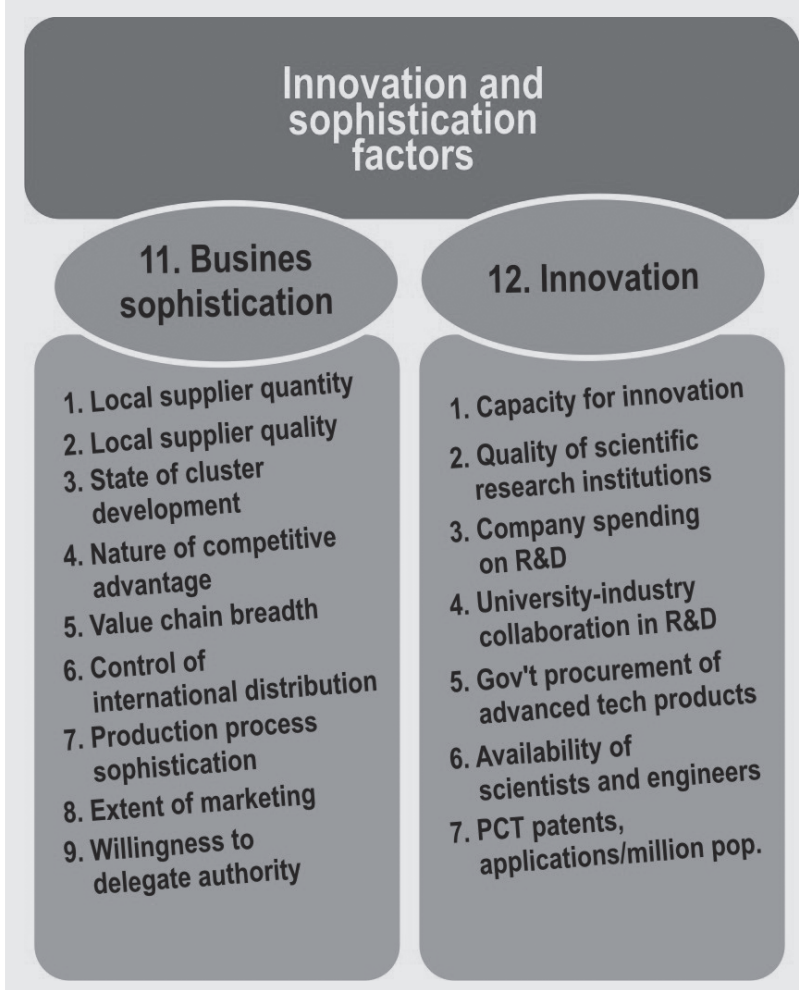

SouRcE: Authors, with reference to Schwab \& Sala Martín, 2015.

The movement of Business sophistication and Innovation in respect of different groups of countries in the period 2006-2015 is illustrated by Figures 14 and 15. Figures also include the value of GDP per capita, which reflects the achieved level of economic development.

FIGURE 14: Average values for the non-

EU neighboring countries group

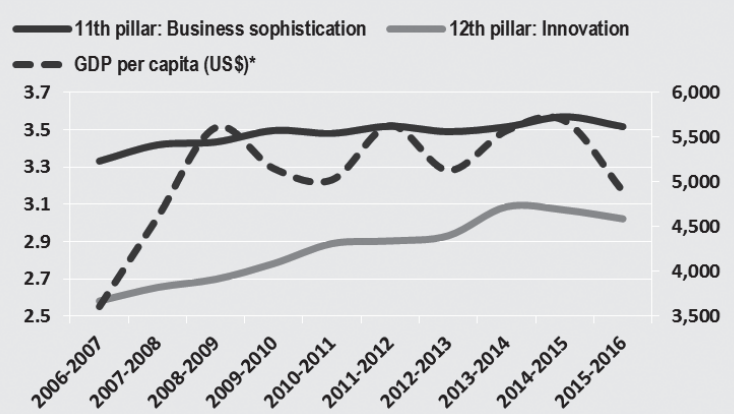

SoURCE: Calculated according to Global Competitiveness Report 2015-2016. (n.d.) 
Figure 14 shows that although non-EU countries show a significant lag of the component Innovation in relation to the component Business sophistication, there is a slight but constant growth trend of both components observed. Innovation shows slightly faster growth trend, reflecting the slow progress of this group of countries towards innovation-driven economies. This indicates the convergence potential of the $11^{\text {th }}$ and $12^{\text {th }}$ GCI pillars. In relation to them, GDP per capita records pronounced fluctuations over time, but its trend has a growing character.

Figure 15 shows the time change of the observed indicators in the group of EU countries. The correlation of Business sophistication and Innovation in this group of countries also shows a significant gap (to the detriment of the component Innovation). There is a slight indication of their mutual convergence at the end of the period, but it is, unfortunately, the result of the fall of Business sophistication, rather than increase in Innovation. In the group of EU neighboring countries, what worries is the economic growth indicator (represented through GDP per capita), which, judging by the whole period observed, has a declining trend.

\section{FiguRE. 15: Average values for the}

\section{EU neighboring countries group}

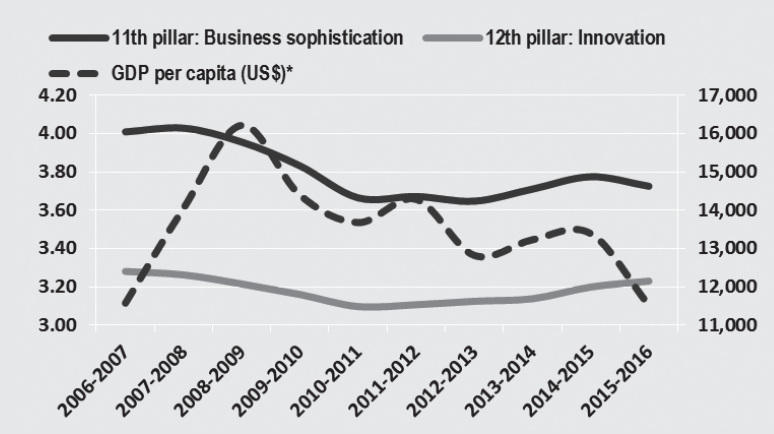

Source: Calculated according to Global Competitiveness Report 2015-2016. (n.d.)

Based on the above analysis, the following conclusion can be drawn: Basic \& Efficiency factors based competitiveness is still dominant in both groups of countries; Innovation \& Sophistication factors based competitiveness, as non-dominant competitiveness (for both groups of countries observed) is largely based on Business sophistication. The implication of the above is that the weakest link in the "chain of national competitiveness" of the countries observed is the $12^{\text {th }}$ pillar, Innovation, whose potential has yet to be activated. The positive fact is that non-EU group of countries (which has the poorest innovative performance) still shows a slight but unmistakable growth trend of Innovation and Business sophistication, as well as their convergence.

\section{BUSINESS SOPHISTICATION AND INNOVATION PILLAR INDICATORS IN THE OBSERVED GROUPS OF COUNTRIES, WITH SPECIAL FOCUS ON THE INDICATOR EXTENT OF MARKETING}

The next section provides an overview of indicators of the $11^{\text {th }}$ and $12^{\text {th }}$ pillars of competitiveness in the period from 2006 to 2015.

Business sophistication indicator is the $11^{\text {th }}$ pillar, and includes factors that increase the efficiency of production of goods and services, which, through increased productivity, improves competitiveness of the national economy. The indicator refers to the quality of business networks, as well as operations and strategies of individual companies. Along with Innovation, this indicator is a key success factor in innovation-driven economies.

Figure 16 shows that out of I \& S competitiveness indicators, non-EU group of countries, in absolute terms, shows the best results in the field of Local supplier quality and Local supplier quantity, but also with the indicator Extent of marketing and Availability of scientists and engineers. However, while the indicator Extent of marketing has a stable upward trend, the other mentioned indicator, Availability of scientists and engineers, which is very important for the innovative component of competitiveness, shows a significant decrease in the last two years of the observed period. The lowest values of non-EU group of countries are recorded in respect of the indicator Company spending on $R \& D$ (which is especially critical for innovation). The low level of indicator State of cluster development is also worrying (but it is at a significantly higher level compared to the crisis period 2008-2009).

Figure 17 gives an insight into the absolute values of the I\&S competitiveness indicators for the group of EU countries neighboring Serbia. It can be concluded that the order of indicators' results is similar to the previously observed group of non-EU countries. Somewhat better relative position of the indicator Quality of scientific research institutions is noted, and the weaker position of the indicator Extent of marketing. (Stanković, Đukić \& Popović, 2014). Moreover, 


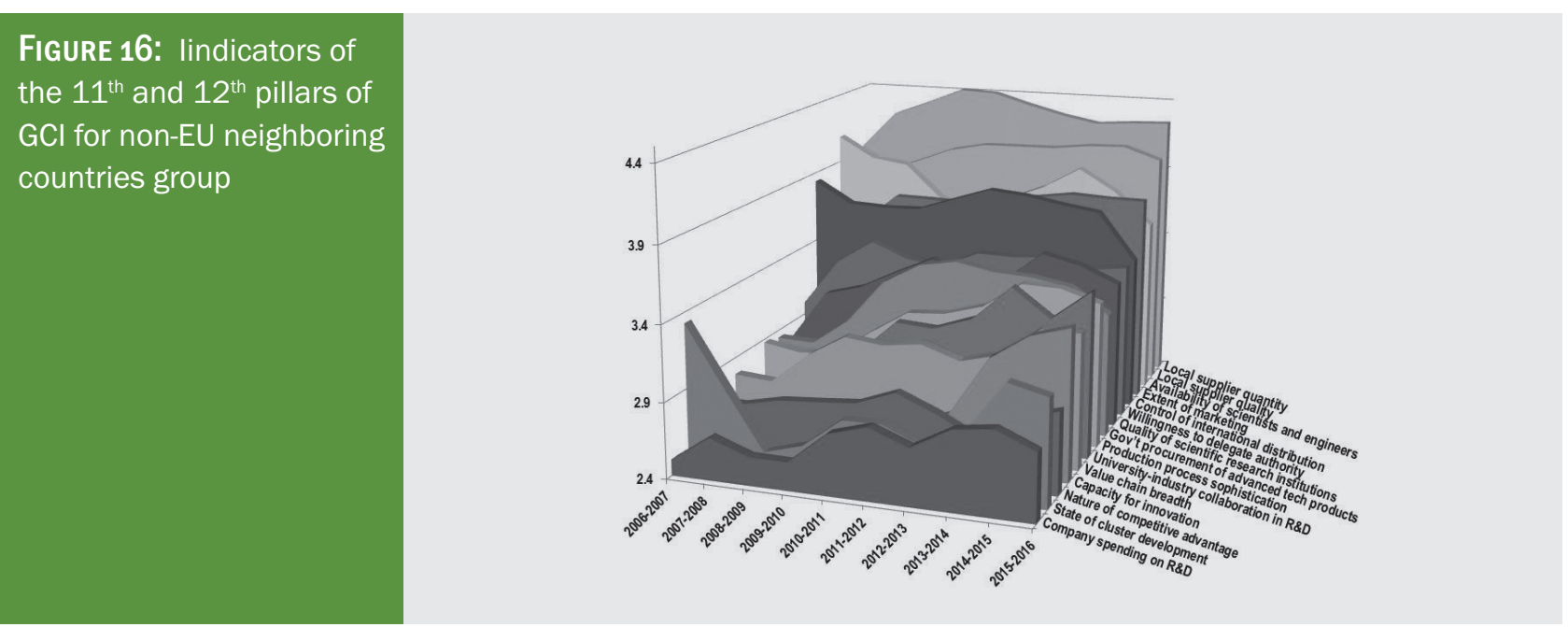

SouRcE: Calculated according to Global Competitiveness Report 2015-2016. (n.d.)
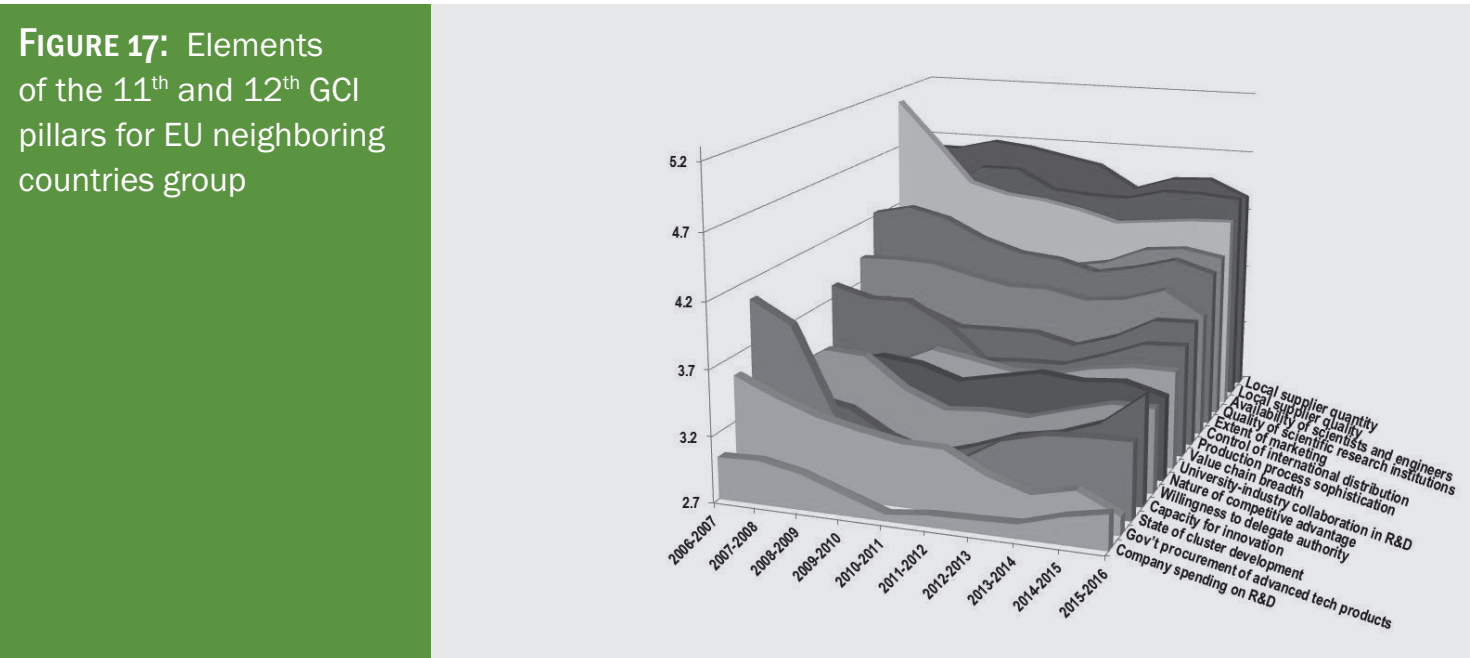

SouRcE: Calculated according to Global Competitiveness Report 2015-2016. (n.d.)

in the EU neighboring countries, the constant downward trend in the value of the indicator Government procurement of advanced tech products is worrying.

\section{CONCLUSION}

Serbia is lagging behind all EU neighboring countries for the period 2006-2015, by level of competitiveness. Compared to neighboring countries which are not members of the EU, competitiveness of the economy of the Republic of Serbia is slightly lower, with the exception of the competitiveness of Albania. Non-EU neighboring countries of Serbia are lagging behind the group of EU countries, by all indicators. Data for the observed period (2006-2015) reveal strong trend of convergence of competitiveness of these two groups of countries.

Competitiveness of the observed countries is predominantly based on Basic \& Efficiency factors based competitiveness. This implies the problem of underused potential of innovation and business sophistication for improving national competitiveness of both groups of countries observed. What partly encourages is the fact that non-EU group of observed countries (which are, in the European context, at the bottom, judging by the achieved GCI ranking) shows a slight but indisputable growth trend of both business sophistication and innovation at the national level.

Statistička analiza indicira moguću iscrpljenost potencijala B\&E konkurentnosti kod EU group of countries i imperativ baziranja njihove konkurent- 
nosti na faktorima inovativnosti i sofisticiranosti. However, in the long run, the two groups of countries will be forced to refocus their future competitiveness on developing innovation and sophistication of their economies, as well as the wider community, towards which, by nature, innovation is directed (in the broad sense), as a future key development imperative.

\section{References}

1. Annoni, P. and Kozovska, K. (2010) EU regional competitiveness index. Luxembourg, European Commission.

2. Despotović, D. (2014). Konkurentnost privrede grada Kragujevca. Stanje i perspektive ekonomskog razvoja grada Kragujevca / redaktori Ljiljana Maksimović, Nenad Stanišić. - Kragujevac: Ekonomski fakultet Univerziteta, str. 39-51.

3. Despotovic, D., Cvetanović, S. and Nedić, V. (2014) Innovativeness and competitiveness of the Western Balkan countries and selected EU member states. Industrija, 42(1), pp. 27-45.

4. Dragičević, M. (2012) Konkurentnost: Projekat za Hrvatsku, Zagreb: Školska knjiga.

5. Global Competitiveness Report 2015-2016. (n.d.). Retrieved March 26, 2016, from http:// reports.weforum.org/global-competitivenessreport-2015-2016/

6. Hawkins, J. (2006). The concept of competitiveness. Treasury.

7. Huggins, R. (2005). Creating a UK Competitiveness Index: Regional and Local Benchmarking. Regional Studies. 37(1), pp. 89-96.

8. Ketels, C. (2003). Thailand's competitiveness: Key issues in five clusters. Unpublished mss., Harvard Business School, Cambridge, Mass. Processed

9. Ketels, H. (2006). Michael Porter's Competitiveness Framework - Recent Learnings and New Research Prioriteies. Journal of Industry Competition and Trade, 6 (2), pp. 115-136.

10. Kitson M., Martin, R. and Tyler P. (2004). Regional Competitiveness: An Elusive yet Key Concept? Regional Studies 38(9), pp. 991-999.

11. Krugman, P. (1994). Competitiveness: A Dangerous Obsession. Foreign Affairs, 73(2), pp. 28-44.

12. Krugman, P. (1996). Making sense of the competitiveness debate. Oxford review of economic policy, pp. 17-25

13. Martin, R. (2004). A Study on the Factors of Regional Competitiveness, A draft final report for the European Commission Directorate-General Regional Policy, European Commission.

14. Martin, R. L. (2003). A study on the factors of regional competitiveness. Available from Internet: http://ec. europa.eu/regional_policy/sources/docgener/studies/ pdf.
15. Nedić V. i Despotović D. (2014). Komparativna analiza konkurentnosti regiona republike srbije u periodu 2005-2013. godine. Četvrti sinpozijum: Regionalne disproporcije u razvoju Srbije, migracije i demografska reprodukcija, Centar za naučna istraživanja SANU. Niš.

16. Porter, M. (1990). The competitive advantage of nations. London: MacMillan Press.

17. Porter, M. E. (1998). Clusters and Competition. New Agenda for Companies. In Governments and Institutions, in: Ibid., On Competition.

18. Powell, T. (2001). The Knowledge Value Chain (KVC): how to fix it when it breaks. In NATIONAL ONLINE MEETING (Vol. 22, pp. 301-312). Information Today, Inc; 1999.

19. Schuller, B. J. (2008). Globalization And Competitiveness Of Nations-The Baltic States. Economics \& Management.

20. Schuller, B. J. and Lidbom, M. (2009). The Enlargement of the EU since 2000-Economic Aspects and Challanges. In The 11th Annual SNEE European Integration Conference: European Integration in Swedish Economic Research. SNEE.

21. Schwab K and Porter M. (Eds.) (2008) Global Competitiveness Report 2008-2009. Geneva: World Economic Forum.

22. Schwab, K. and Porter, M. (Eds.) (2007). The global competitiveness report 2007-2008. Basingstoke: Palgrave Macmillan.

23. Schwab, K., Sala-i-Martin, X., Semans, R. and Blanke, J. (2014). The Global Competitiveness Report 20142015. Report of the World Economic Forum. ISBN 978-92-95044-98-2.

24. Snieška V. and Bruneckienė J. (2009). Measurement of Lithuanian Regions by Regional Competitiveness Index. Engineering economics 20(1), pp. 45-57.

25. Stanković, Lj., Đukić, S. i Popović, A. (2014). Marketing inovacije kao izvor konkurentske prednosti preduzeća. Marketing 4(45), 271-282.

26. Zubović, J. and Bradić-Martinović, A. (2014). Competitiveness of Nations in selected SEE Countries. Procedia Economics and Finance, 8, 755762. 


\section{Apstrakt}

\section{Konkurentnost selektovanih zemalja Balkana u periodu 2006-2015.}

Vladimir Nedić, Vinko Lepojević, Danijela Despotović, Dušan Cvetanović

U radu je istraživan nivo konkurentnosti dve grupe balkanskih zemalja. Prvu grupu čine zemlje iz bližeg okruženja Republike Srbije koje su nečlanice EU (Albanija, Bosna i Hercegovina, Makedonija, Crna Gora, Srbija) a drugu grupu čine pet zemalja članice EU (Bugarska. Hrvatska, Grčka, Mađarska i Rumunija). Period na koje se istraživanje odnosi se proteže od 2006. do 2015. godine. Nivo konkurnentosti zemalja sagledavan je putem vrednosti globalnog indeksa konkurentnosti Svetskog ekonomskog foruma. Pri tom je posebno sagledavana konkurentnost zemlje koju generiše posedovanje i efikasna upotreba faktora proizvodnje (Basic \& Efficiency factors based com- petitiveness), s jedne i konkurentnost bazirana na osnovu inovativnosti i sofisticiranosti poslovanja (Innovation \& Sophistication factors based competitiveness) s druge strane. Došlo se do zaključka da grupa ne-EU zemalja zaostaju po svim pokazateljima za grupom EU zemalja. Međutim, podaci u ispitivanom periodu otkrivaju izražen trend konvergencije konkurentnosti ovih grupa zemalja.

Ključne reči: konkurentnost zemlje, osnovni faktori, faktori efikasnosti, inovativnost i sofisticiranost poslovanja, GDP per capita

\section{Kontakt:}

Vladimir Nedić,

School of Applied Engineering Studies, Kragujevac, Serbia, vnedic@kg.ac.rs

Vinko Lepojević, Faculty of Economics, University of Niš, vinko.lepojevic@eknfak.ni.ac.rs

Danijela Despotović, Faculty of Economics, University of Kragujevac, ddespotovic@kg.ac.rs

Dušan Cvetanović, doctoral student at Faculty of Economics, University of Niš, dusan.cvetanovic@ymail.com 